\title{
Strategies for Keeping Your Family Connected
}

\section{Kimberly Eddleston (Northeastern University)}

KEYWORDS: Family Business, Conflict, human resources.

In her second interview with Familybusiness.org, Mitzi Perdue shares strategies from her book entitled How to Keep Your Family Connected. (https://www.amazon.com/Keep-Your-Family-Connecte d-Strengthening/dp/1976243874/ref=sr_1_1?keywords $=$ How+to+keep+your+family+connected+Perdue \&qid $=1$ 638789786\&sr=8-1) This workbook, which complements her book How to Make Your Family Business Last,(https://mitziperdue.com) has templates and instructions for activities that reinforce family unity.

Perdue is the widow of Frank Perdue and the daughter of Ernest Henderson Sr., a founder of the Sheraton Hotels empire. She also runs a consultancy devoted to family business success. Her workbook was inspired by her father's tradition of regularly sharing stories and lessons with his children; and by her own experience creating a newsletter that shared her husband's wisdom with the rest of the Perdue family. The downloadable template (above), from Perdue's workbook, shows how to think through and create a family newsletter.

In this interview with familybusiness.org Editor Kimberly Eddleston, Perdue discusses strategies based on her workbook for helping older generations share their wisdom and experiences with younger ones and strengthen commitment to the family and the business.

Copyright @ 2022 The Authors. Entrepreneur \& Innovation Exchange is published at EIX.org. This is an open access article under the terms of the Creative Commons Attribution-NoDerivs License, which permits use and distribution in any medium, provided the original work is properly cited and 